\title{
Assessment of the Indoor Air Quality of Majors’ Biological Laboratories in Ofrima Complex, University of Port-Harcourt, Nigeria
}

\section{Mbakwem-Aniebo $\mathrm{C}^{1}$, Stanley $\mathrm{HO}^{1 *}$ and Onwukwe $\mathrm{CD}^{2}$}

${ }^{1}$ Department of Microbiology, Faculty of Biological Sciences, University of Port Harcourt, P. M. B. 5323, Choba, 500004 Port Harcourt, Rivers State, Nigeria ${ }^{2}$ Department of Microbiology and Technology, School of Science, Laboratory of Technology, University of Port Harcourt, P. M. B. 5323, Choba, 500004 Port Harcourt, Rivers State, Nigeria

\begin{abstract}
The study was carried out to assess the genera of airborne micro-organisms present in the indoor environment of Microbiology and Animal/Environmental Biology Majors' laboratories in University of Port Harcourt; which could cause infection to laboratory users and contamination of culture. Indoor air was assessed (at $9 \mathrm{am}, 12 \mathrm{pm}$ and $4 \mathrm{pm}$ ) for five days and the basic parameters in this study were number of individuals present at each exposure time, time of sampling and duration. The settling plate technique was employed as sample collection method. The total heterotrophic bacterial and total fungal count from Microbiology Majors' laboratory was $987 \mathrm{CFU} / \mathrm{m}^{2} / \mathrm{h}$ (Colony Forming Unit per square meters per hour) $(80.18 \%)$ and $244 \mathrm{SFU} / \mathrm{m}^{2} / \mathrm{h}$ (Spore Forming Unit per square meters per hour) $(19.82 \%)$ respectively while the total heterotrophic bacterial and total fungal count from Animal/Environmental Biology Majors' laboratory was $677 \mathrm{CFU} / \mathrm{m}^{2} / \mathrm{h}(79.27 \%)$ and $177 \mathrm{SFU} / \mathrm{m}^{2} / \mathrm{h}(20.73 \%)$ respectively, reported as contamination flow. In the examined area, the predominant culturable species of air borne microflora were members of bacteria genera; Bacillus, Staphylococcus, Escherichia, Micrococcus, Pseudomonas, Serratia, Acinetobacter and fungi; Aspergillus, Cladosporium, Fusarium, Penicillium, Rhodotorula, Trichophyton, Candida, Mucor, Rhizopus, Scopulariopsis and Trichoderma. Despite the high number counted plates in both laboratories, the data proves to be statistically insignificant at $\mathrm{P}=0.05$ for 9 am and $4 \mathrm{pm}$ while significant at 12 noon for laboratories 1 and 2 . Both laboratories are were undergraduate science students of the University of Port Harcourt in the faculty of biological sciences carry out their ressearch and study.
\end{abstract}

Keywords: Assessment; Air quality; Laboratory environment; Ofrima complex; University of Port Harcourt

\section{Introduction}

Air is a carrier of particulate matter, dust and droplets which remain generally laden with microorganism but not a natural medium for microorganisms. Air transports the microorganisms and the ultimate fate of such microorganisms depends on factors such as sunlight, temperature, humidity, size of microorganism, laden particulate degree of susceptibility or resistance of a particular microorganism to form resistant spores or cyst [1]. Airborne microorganisms originate from different sources such as soil, animals and humans [2-4].

In many human activities, micro-organisms in the environment represent a hidden but dangerous risk factor [5].

The activities of men such as sewage treatment plants, animal rendering, fermentation processes, construction works and agricultural activities play a major role in emitting microorganisms into the air $[6,7]$.

Exposure to bio-aerosol in the occupational environment are associated with a wide range of health effects with major public health impact, including infectious disease, acute toxic effects, allergies and cancer.

The microbial quality of indoor air in a given space at a particular time period is said to be determined by the quality of air entering the space, the number of occupants in the space, their physical activities and resultant aerosol generation, human traffic and ventilation of the area [8].

Indoor air quality (IAQ) is becoming an increasingly important issue for occupational and public health $[9,10]$.

Droplets can be propelled up to 6-12 feet depending on the size of the droplets and the force of expulsion. The largest droplets are more likely to fall to the floor or ground fairly rapidly. Medium sized pathogenic droplets are more likely to enter the nasopharynx of someone nearby, and can adhere to nasopharyngeal epithelial cells where they can cause infection [11].

Diseases associated with inhalation of fungal spores include toxic pneumonitis, hypersensitivity pneumonitis, tremors, chronic fatigue syndrome, kidney failure, and cancer [12].

Aspergillus fumigatus is the most prevalent cause of severe pulmonary allergic disease, including allergic bronchopulmonary aspergillosis (ABPA), known to be associated with chronic lung injury and deterioration in pulmonary function in people with chronic asthma and cystic fibrosis (CF) [13].

Since air can play a central role as a reservoir for microorganisms, regular microbial monitoring is useful to assess air quality and identify critical situations [14].

This study is therefore aimed at assessing the airborne microorganisms present in the indoor laboratory environment that

"Corresponding author: Stanley HO, Department of Microbiology, Faculty of Biological Sciences, University of Port Harcourt, P. M. B. 5323, Choba, 500004 Port Harcourt, Rivers State, Nigeria, E-mail: okehstanley@yahoo.com

Received April 22, 2016; Accepted May 30, 2016; Published June 08, 2016

Citation: Aniebo CM, Stanley HO, Onwukwe CD (2016) Assessment of the Indoor Air Quality of Majors' Biological Laboratories in Ofrima Complex, University of Port-Harcourt, Nigeria. J Pet Environ Biotechnol 7: 285. doi: 10.4172/2157. 7463.1000285

Copyright: ( 2016 Aniebo CM, et al. This is an open-access article distributed under the terms of the Creative Commons Attribution License, which permits unrestricted use, distribution, and reproduction in any medium, provided the original author and source are credited. 
could possibly cause contamination of culture media and infection of laboratory workers and students as they often make use of the laboratory.

\section{Methods}

\section{Sample collection and number of plates exposed}

The settling plate technique also known as sedimentation method was used as sample collection method [15]. In this technique, standard $90 \mathrm{~mm}$ diameter Petri dishes containing $20 \mathrm{ml}$ of sterile culture media (Nutrient Agar and Potato Dextrose Agar) were opened at the various sampling locations for 1 hour. After which the Petri dishes containing nutrient agar were closed and placed in the incubator at $37^{\circ} \mathrm{C}$ for possible bacterial growth within 18 to 24 hours, whereas Petri dishes containing potato dextrose agar were incubated at room temperature for 5 days.

This technique of sample collection is known as $1 / 1 / 1$ scheme, 1 hour of exposure, 1 metre from the floor and 1 meter from the wall or obstruction as described by Pasquarella [5].

A total number of 16 plates were exposed at each exposure time; these comprised of 8 Nutrient agar plates (4 in Animal and Environmental Biology Majors' laboratory (designated as Lab 2) and 4 in Microbiology Majors' laboratory (designated as Lab 1) and 8 Potato Dextrose agar plates (4 in Animal and Environmental Biology Majors' laboratory and 4 in Microbiology Majors' laboratory and this was carried out 3 times in a day ( 9 am - when the number of students and staff present are minimal; $12 \mathrm{pm}$ - when the work force in the laboratory is at its peak and $4 \mathrm{pm}$ - when the day's work is done and students and staff are about leaving the laboratory). The total number of individuals present in the different laboratory at each time of exposure was noted. Isolates were identified by their cultural, morphological and biochemical characteristics as described by many researchers [16,17].

Colony forming unit (CFU) and Spore forming unit (SFU) of the bioaerosols (bacteria and fungi respectively) were assessed (3 times a day) for five days, taking into consideration the number of individuals present at each exposure time at the sampling sites and the weather conditions at such points.

\section{Results}

The result obtained showed that there were more suspensions of bio aerosols in the indoor air at noon which correlates to the period when more persons were found at the sampling sites. The activities of persons at the sampling sites kept the aerosols airborne at varying dispersal rates and the ambient weather condition which was rainy and not windy at the time of study did not exert much influence on the results obtained.

Table 1 shows the Total heterotrophic bacterial count 987 CFU/ $\mathrm{m}^{2} / \mathrm{h}(59.30 \%$ for Lab 1$)$ and $677 \mathrm{CFU} / \mathrm{m}^{2} / \mathrm{h}(40.69 \%$ for Lab 2). Day five had the highest heterotrophic bacteria count in both laboratories. $314 \mathrm{CFU} / \mathrm{m}^{2} / \mathrm{h}$ and $145 \mathrm{CFU} / \mathrm{m}^{2} / \mathrm{h}$ for Lab 1 and Lab 2 respectively and Total Fungal count $244 \mathrm{SFU} / \mathrm{dm}^{2} / \mathrm{h}(57.96 \%$ for Lab 1) and $177 \mathrm{SFU} /$ $\mathrm{dm}^{2} / \mathrm{h}(42.04 \%$ for Lab 2$)$.

The total heterotrophic bacterial and total fungal count from Microbiology Majors'laboratory was $987 \mathrm{CFU} / \mathrm{m}^{2} / \mathrm{h}$ (80.18\%) and 244 $\mathrm{SFU} / \mathrm{m}^{2} / \mathrm{h}(19.82 \%)$ respectively while the total heterotrophic bacterial and total fungal count from Animal/Environmental Biology Majors' laboratory was $677 \mathrm{CFU} / \mathrm{m}^{2} / \mathrm{h}(79.27 \%)$ and $177 \mathrm{SFU} / \mathrm{m}^{2} / \mathrm{h}(20.73 \%)$ fungal count respectively, reported as contamination flow. Tables $2 \mathrm{a}$ and $2 \mathrm{~b}$ show the ANOVA for heterotrophic bacteria and fungal plate count obtained from both laboratories.

Data represent mean \pm S.D of triplicate exposure result from Lab 1 and Lab 2. Anova analysis was conducted to check if the data obtained where statistically significant between the data horizontaly and values with the same superscript are not statistically significant at $\mathrm{P}=0.05$, using SPSS Version 17.0.

The most presented microorganisms are Aspergillus spp., Bacillus spp., Staphylococcus spp. in Lab 1 and Lab 2 with different percentages; $37 \%$ and $25 \%, 33.3 \%$ and $18.2 \%, 18.2 \%$ and $17.9 \%$ respectively and Escherichia spp. $25 \%$ only in Lab 1.

\section{Discussion}

The alterations in quality of indoor air in Microbiology Majors' Laboratory (Lab 1) and the Animal and environmental biology majors'

\begin{tabular}{|c|c|c|c|c|c|}
\hline Day & Time & $\begin{array}{l}\text { Mean Bacterial Plate } \\
\text { Count }\left(\mathrm{CFU} / \mathrm{m}^{2} / \mathrm{h}\right)\end{array}$ & $\begin{array}{l}\text { Mean Fungal Plate Count (CFU/ } \\
\left.\mathrm{m}^{2} / \mathrm{h}\right)\end{array}$ & $\begin{array}{l}\text { Mean Bacterial Plate Count (CFU/ } \\
\left.\qquad \mathrm{m}^{2} / \mathrm{h}\right)\end{array}$ & $\begin{array}{l}\text { Mean Fungal Plate Count (CFU/ } \\
\left.\mathrm{m}^{2} / \mathrm{h}\right)\end{array}$ \\
\hline & & \multicolumn{2}{|c|}{ Microbiology Majors' Laboratory (Lab 1) } & \multicolumn{2}{|c|}{ Animal/Environmental Biology Majors' Laboratory (Lab 2) } \\
\hline 1 & 9 am & 33 & 10 & 16 & 9 \\
\hline 1 & $12 \mathrm{pm}$ & 50 & 22 & 24 & 17 \\
\hline 1 & $4 \mathrm{pm}$ & 44 & 13 & 17 & 7 \\
\hline 2 & $9 \mathrm{am}$ & 15 & 10 & 19 & 7 \\
\hline 2 & $12 \mathrm{pm}$ & 81 & 17 & 38 & 19 \\
\hline 2 & $4 \mathrm{pm}$ & 49 & 19 & 11 & 16 \\
\hline 3 & $9 \mathrm{am}$ & 27 & 22 & 5 & 5 \\
\hline 3 & $12 \mathrm{pm}$ & 128 & 42 & 40 & 4 \\
\hline 3 & $4 \mathrm{pm}$ & 21 & 25 & 17 & 8 \\
\hline 4 & $9 \mathrm{am}$ & 17 & 6 & 20 & 4 \\
\hline 4 & $12 \mathrm{pm}$ & 27 & 10 & 72 & 17 \\
\hline 4 & $4 \mathrm{pm}$ & 16 & 18 & 107 & 20 \\
\hline 5 & $9 \mathrm{am}$ & 49 & 8 & 27 & 11 \\
\hline 5 & $12 \mathrm{pm}$ & 314 & 5 & 145 & 19 \\
\hline 5 & $4 \mathrm{pm}$ & 116 & 17 & 119 & 14 \\
\hline \multicolumn{2}{|c|}{ Total } & $987(59.30 \%)$ & $244(57.96 \%)$ & $677(40.69 \%)$ & $177(42.04 \%)$ \\
\hline
\end{tabular}

Table 1: Total heterotrophic bacterial and fungal count. 


\begin{tabular}{|c|c|c|c|}
\hline \multirow{2}{*}{ Day } & \multirow{2}{*}{ Time } & \multicolumn{2}{|c|}{ Laboratories } \\
\cline { 2 - 4 } & $9 \mathrm{am}$ & $33.00 \pm 1.00^{\mathrm{a}, \mathrm{d}}$ & $16.00 \pm 1.00^{\mathrm{a}, \mathrm{e}}$ \\
\hline \multirow{3}{*}{1} & $12 \mathrm{pm}$ & $50.00 \pm 1.00^{\mathrm{b}, \mathrm{d}}$ & $24.00 \pm 1.00^{\mathrm{b}, \mathrm{e}}$ \\
\hline & $4 \mathrm{pm}$ & $44.00 \pm 1.00^{\mathrm{c}, \mathrm{d}}$ & $17.00 \pm 100^{\mathrm{a}, \mathrm{e}}$ \\
\hline \multirow{3}{*}{2} & $9 \mathrm{am}$ & $15.00 \pm 1.00^{\mathrm{a}, \mathrm{d}}$ & $19.00 \pm 1.00^{\mathrm{a}, \mathrm{e}}$ \\
\hline & $12 \mathrm{pm}$ & $80.00 \pm 1.00^{\mathrm{b}, \mathrm{d}}$ & $38.00 \pm 1.00^{\mathrm{b}, \mathrm{e}}$ \\
\hline \multirow{3}{*}{3} & $4 \mathrm{pm}$ & $49.00 \pm 1.00^{\mathrm{c}, \mathrm{d}}$ & $11.00 \pm 1.00^{\mathrm{c}, \mathrm{e}}$ \\
\hline \multirow{3}{*}{3} & $9 \mathrm{am}$ & $27.00 \pm 1.00^{\mathrm{a}, \mathrm{d}}$ & $5.00 \pm 1.00^{\mathrm{a}, \mathrm{e}}$ \\
\hline \multirow{3}{*}{4} & $12 \mathrm{pm}$ & $128.00 \pm 1.00^{\mathrm{b}, \mathrm{d}}$ & $39.67 \pm 0.5^{\mathrm{b}, \mathrm{e}}$ \\
\hline & $4 \mathrm{pm}$ & $21.00 \pm 1.00^{\mathrm{c}, \mathrm{d}}$ & $17.00 \pm 1.00^{\mathrm{c}, \mathrm{e}}$ \\
\hline \multirow{3}{*}{5} & $9 \mathrm{am}$ & $17.00 \pm 1.00^{\mathrm{a}, \mathrm{d}}$ & $20.00 \pm 1.00^{\mathrm{a}, \mathrm{e}}$ \\
\hline \multirow{3}{*}{5} & $12 \mathrm{pm}$ & $27.00 \pm 1.00^{\mathrm{b}, \mathrm{d}}$ & $72.00 \pm 1.00^{\mathrm{b}, \mathrm{e}}$ \\
\hline & $4 \mathrm{pm}$ & $16.00 \pm 1.00^{\mathrm{a}, \mathrm{d}}$ & $107.00 \pm 1.00^{\mathrm{c}, \mathrm{e}}$ \\
\hline & $9 \mathrm{am}$ & $49.00 \pm 1.00^{\mathrm{a}, \mathrm{d}}$ & $27.00 \pm 1.00^{\mathrm{a}, \mathrm{e}}$ \\
\hline & $12 \mathrm{pm}$ & $314.00 \pm 2.00^{\mathrm{b}, \mathrm{d}}$ & $145.00 \pm 1.00^{\mathrm{b}, \mathrm{e}}$ \\
\hline & $4 \mathrm{pm}$ & $116.00 \pm 2.00^{\mathrm{c}, \mathrm{d}}$ & $119.00 \pm 1.00^{\mathrm{c}, \mathrm{e}}$ \\
\hline
\end{tabular}

Data represent mean \pm S.D of triplicate exposure result from both Laboratories. Anova analysis was conducted to check if the data obtained where statistically significant between the data vertically and horizontaly and values with the s AMe superscript are not statistically significant while mean with different superscripts are statistically significant at $P=05$, using SPSS Version 17.0 . Superscript $a, b, c$ compares microbial count with time(hours)along the rows while superscript $d, e$ compares microbial count in both Laboratories.

$\mathrm{AEB}=$ Animal/Environmental Biology

Table 2a: ANOVA for mean bacterial count from both Laboratories (CFU/ml).

\begin{tabular}{|c|c|c|c|}
\hline \multirow{2}{*}{ Days } & \multirow{2}{*}{ Time } & \multicolumn{2}{|c|}{ Laboratories } \\
\cline { 2 - 4 } & & Mean \pm S.D Lab 1 & Mean \pm S.D Lab 2 \\
\hline \multirow{3}{*}{1} & $9 \mathrm{am}$ & $10.00 \pm 2.00^{\mathrm{a}, \mathrm{d}}$ & $9.00 \pm 1.00^{\mathrm{a}, \mathrm{d}}$ \\
\cline { 2 - 4 } & $12 \mathrm{pm}$ & $22.00 \pm 1.00^{\mathrm{b}, \mathrm{d}}$ & $17.00 \pm 1.00^{\mathrm{b}, \mathrm{e}}$ \\
\cline { 2 - 4 } & $4 \mathrm{pm}$ & $13.00 \pm 1.00^{\mathrm{a}, \mathrm{d}}$ & $7.00 \pm 1.00^{\mathrm{a}, \mathrm{e}}$ \\
\hline \multirow{3}{*}{2} & $9 \mathrm{am}$ & $10.00 \pm 1.00^{\mathrm{a}, \mathrm{d}}$ & $7.00 \pm 1.00^{\mathrm{a}, \mathrm{d}}$ \\
\cline { 2 - 4 } & $12 \mathrm{pm}$ & $17.00 \pm 1.00^{\mathrm{b}, \mathrm{d}}$ & $19.00 \pm 1.00^{\mathrm{b}, \mathrm{d}}$ \\
\cline { 2 - 4 } & $4 \mathrm{pm}$ & $19.00 \pm 1.00^{\mathrm{b}, \mathrm{d}}$ & $16.00 \pm 1.00^{\mathrm{c}, \mathrm{d}}$ \\
\hline \multirow{3}{*}{3} & $9 \mathrm{am}$ & $22.00 \pm 1.00^{\mathrm{a}, \mathrm{d}}$ & $5.00 \pm 1.00^{\mathrm{c}, \mathrm{d}}$ \\
\cline { 2 - 4 } & $12 \mathrm{pm}$ & $42.00 \pm 1.00^{\mathrm{b}, \mathrm{d}}$ & $4.00 \pm 1.00^{\mathrm{a}, \mathrm{e}}$ \\
\cline { 2 - 4 } & $4 \mathrm{pm}$ & $25.00 \pm 1.00^{\mathrm{c}, \mathrm{d}}$ & $8.00 \pm 1.00^{\mathrm{b}, \mathrm{e}}$ \\
\hline \multirow{3}{*}{4} & $9 \mathrm{am}$ & $6.00 \pm 1.00^{\mathrm{a}, \mathrm{d}}$ & $4.00 \pm 100^{\mathrm{a}, \mathrm{d}}$ \\
\cline { 2 - 4 } & $12 \mathrm{pm}$ & $10.00 \pm 1.00^{\mathrm{b}, \mathrm{d}}$ & $17.00 \pm 1.00^{\mathrm{b}, \mathrm{e}}$ \\
\cline { 2 - 4 } & $4 \mathrm{pm}$ & $18.00 \pm 1.00^{\mathrm{c}, \mathrm{e}}$ & $20.00 \pm 1.00^{\mathrm{c}, \mathrm{e}}$ \\
\hline \multirow{3}{*}{5} & $9 \mathrm{am}$ & $8.00 \pm 1.00^{\mathrm{a}, \mathrm{d}}$ & $11.00 \pm 1.00^{\mathrm{a}, \mathrm{e}}$ \\
\cline { 2 - 4 } & $12 \mathrm{pm}$ & $5.00 \pm 1.00^{\mathrm{b}, \mathrm{d}}$ & $19.00 \pm 1.00^{\mathrm{b}, \mathrm{e}}$ \\
\cline { 2 - 4 } & $4 \mathrm{pm}$ & $17.00 \pm 1.00^{\mathrm{c}, \mathrm{d}}$ & $14.00 \pm 1.00^{\mathrm{c}, \mathrm{e}}$ \\
\hline
\end{tabular}

Data represent mean \pm S.D of triplicate exposure result from both Laboratories. Anova analysis was conducted to check if the data obtained where statistically significant between the data vertically and horizontaly and values with the s AMe superscript are not statistically significant while mean with different superscripts are statistically significant at $P=.05$, using SPSS Version 17.0 . Superscript $a, b, c$ compares microbial count with time(hours)along the rows while superscript $d, e$ compares microbial count in both Laboratories.

Table 2b: ANOVA for mean fungal count from both Laboratories (SFU/ml).

laboratory (Lab 2) in Ofrima Complex of University of Port Harcourt showed increase with increasing human population and activities.

Bacterial isolates were presented more on day 5 (Lab 1 and Lab 2) (Figure 1), while Fungal isolates were presented more on day 3 (Lab 1). This could be as a result of human activities which caused the organism to be airborne. On the average, the study sites were more occupied by research students and staff at noon and the activities of these individual and the flora carried by them influenced the plate counts as organisms were counted more at noon. At all times, Lab 1 was more populated compared to Lab 2, and corresponding to this, it also had more count of organisms on the average (Figure 2a).

Biochemical characterization of bacterial isolates (flora composition) of (Lab 1) sampling station revealed the bacterial species present as shown above with, Bacillus, Staphylococcus, Escherichia, Micrococcus, Pseudomonas and Serratia being the predominant genera in (Lab 1) and Acinetobacter, Bacillus, Escherichia and Staphylococcus being the most dominant in Animal and environmental biology laboratory (Lab 2). These isolates are commonly found bio aerosols and pathogens in the air. This is because the carriers are commonly present in the area under study. This supports previous studies which state that Staphylococcus sp is the most commonly found pathogen in air $[15,18]$.

Staphylococcus is found in all individuals and usually expelled from the respiratory tract through the nose and mouth which may also account for their presence in the environment and can cause bacteremia and gastrointestinal infections [19]. Bacillus species are persistent and resistant in the environment because of the formation of spores. Spores have since been recognized as the hardest known form of life on Earth [20].

The production of spores enables this organism to withstand unfavourable conditions such as low temperatures or heat and may improve the chances of Bacillus to be present in high numbers in the air [21]. Escherichia spp. can be found in the normal intestinal flora of humans and animals but can also be an important cause of enteric illness and constitute the major etiologic agent of sporadic and epidemic diarrhea both in children and adults [22].

The laboratory analysis also showed that Aspergillus, Cladosporium, Fusarium, Penicillium, Rhodotorula and Trichophyton species were predominat fungal isolates in (Lab 1) and Aspergilus, Candida, Mucor, Penicillium, Rhizopus, Scopulariopsis and Trichoderma species were predominant in (Lab 2) (Figure 2b).

These genera of bacteria and fungi have been shown to be amongst the most common bacterial and fungal genera often isolated from air. Previous studies have also shown that people occupying or visiting enclosed spaces play a dominating role in the creation of indoor microbiological environment [23]. Aspergilus fumigatus is widely distributed in the environment and airborne asexual conidia serves as the main mode of transport for pulmonary lung infection [7,24-28].

The following bacterial and fungal genera; Aeromonas, Enterobacter, Klebsiella, Serratia, Cladosporium, Fusarium, Rhodotorula, and Trichophyton were isolated only from the indoor environment of (Lab 1) but were not found in (Lab 2) indoor air and Acinetobacter, Salmonella, Streptococcus, Geotrichum, Mucor, Scopulariopsis and Trichodema were found only in Animal/ Environmental Biology Majors' Laboratory (Lab 2) and were not found in Microbiology Majors' Laboratory (Lab 1) [29-32]. The Microbiology Majors' Laboratory (Lab 1) had a higher bacterial and fungal percentage count as against the Animal/Environmental Biology Majors' Laboratory (Lab 2).

This could probably be attributed to the more number of individuals usually present in Microbiology Majors' Laboratory and their various research works, which could introduce more organisms to the indoor air. Despite the high number of bacterial and fungal plate count in both laboratories, the data proves to be statistically insignificant at $\mathrm{P}=0.05$ for Microbiology Majors' Laboratory. While the fungal plate and bacterial plate count in Animal/Environmental Biology Majors' Laboratory are statistically significant at $\mathrm{P}=0.05$. From this study, the 


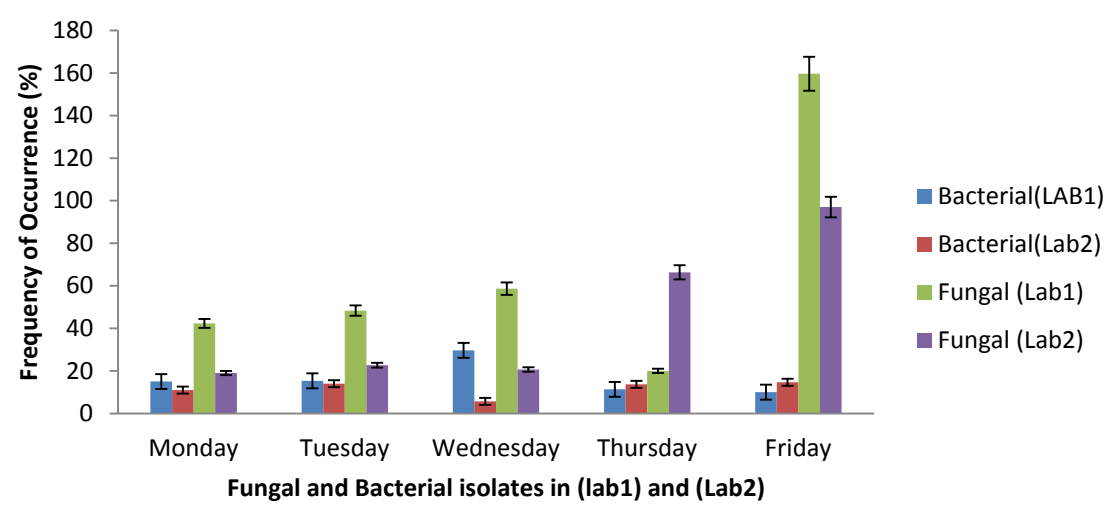

Figure 1: Cumulative distribution of fungal and heterotrophic bacterial isolates in both laboratories on daily basis with percentage error bars.

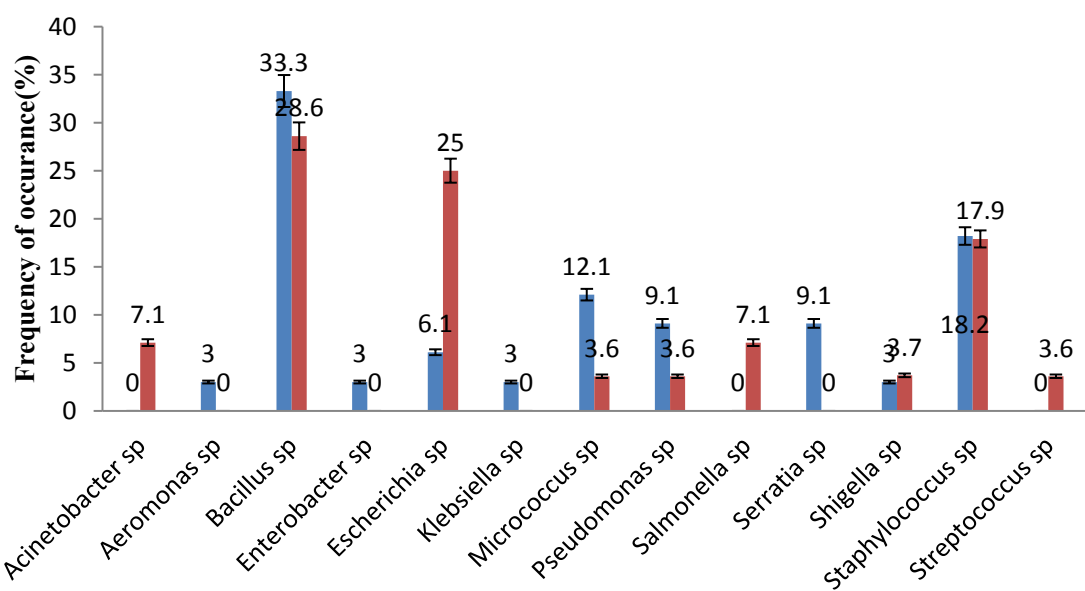

Figure 2a: Frequency of bacterial isolates in microbiology majors' laboratory (Lab 1) and animal and environmental biology majors' laboratory (Lab 2), University of Port Harcourt with percentage error bars.

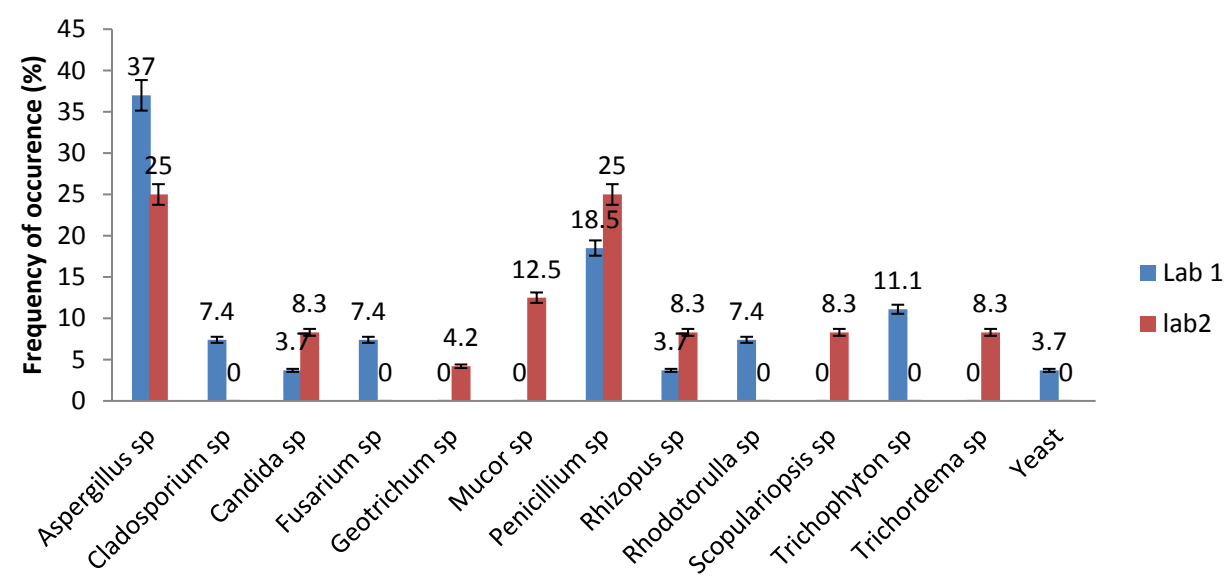

Figure 2b: Frequency of fungal isolates in microbiology majors' laboratory (Lab 1) and animal and environmental majors' laboratory (Lab 2), University of Port Harcourt with percentage error bars.

indoor air of Microbiology Majors' Laboratory (Lab 1) is more laden with micro organisms compared to Animal/Environmental Biology Majors' Laboratory (Lab 2).

\section{Conclusion and Recommendations}

This research has shown that the sample sites are laden with micro organisms and most of which are pathogenic to human and can result in mild or adverse health conditions based on individual health status and dose response. These organisms pose threats to research work as they constantly contaminate plates if proper aseptic technique is not efficiently employed. Therefore, health challenged or immune compromised researchers should ensure to work with nose masks if 
Citation: Aniebo CM, Stanley HO, Onwukwe CD (2016) Assessment of the Indoor Air Quality of Majors' Biological Laboratories in Ofrima Complex, University of Port-Harcourt, Nigeria. J Pet Environ Biotechnol 7: 285. doi: 10.4172/2157-7463.1000285

Page 5 of 5

they must use the laboratory and proper aseptic techniques should be employed in discarding used media plates (autoclave before discarding). Adequate Sanitary measures by laboratory users can help reduce the level of bioaerosols, measures such as disinfecting work benches before and after use. Avoid the practice of sweeping with brooms and use vacuum cleaners or wet mop instead. These technique will help reduce the microbial load of the environment instead of pushing bioaerosols off to the air as observed in the case of sweeping practice.

\section{References}

1. Pelczar MJECS, kriey NR (1993) Microbiology concept and application. McGraw-Hill.

2. Ogugbue CJ, Aniebo M, Akubuenyi C, Felix C (2011) Assessment of microbia air contamination of post processed garri on sale in markets. African Journal of Food Science 5: 505

3. Fang Z, Ouyang Z, Zheng H, Wang X, Hu L (2007) Culturable airborne bacteria in outdoor environments in Beijing, China. African Journal of Microbiology Research 6: 13-412.

4. Pósfai M, Li J, Anderson J, Buseck P (2003) Aerosol bacteria over the Southern Ocean during ACE-1. Atmospheric Research 66: 231-240.

5. Pasquarella C, Pitzurra O, Savino A (2000) The index of microbial air contamination. Journal of Hospital Infection 46: 241-256.

6. Gillum S, Levetin E (2008) The air spora close to a compost facility in Northeas Oklahoma: Part I - spore trap sampling. Aerobiologia 24: 3-12.

7. Recer G, Browne M, Horn E, Hill K, Boehler W (2001) Ambient air levels of Aspergillus fumigatus and thermophilic actinomycetes in a residential neighborhood near a yard-waste composting facility. Aerobiologia 17: 99-108.

8. Ekhaise FO, Isitor EE, Idehen O, Emogbene OA (2010) Airborne microflora in the atmosphere of an hospital environment of University of Benin Teaching Hospital(UBTH), Benin City, Nigeria. World Journal of Agricultural Science 6: 166-170.

9. Reynolds SJ, Black DW, Borin SS, Breuer G, Burmeister LF et al. (2001) Indoo environmental quality in six commercial office buildings in the Midwest United States. Applied Occupational and Environmental Hygiene 16: 1065-1077.

10. Dudzińska M (2011) Volatile organic compounds in private cars and public vehicles. Rocznik Ochrona Środowiska 13: 101-115.

11. Musher DM (2003) How contagious are common respiratory infections? New England Journal of Medicine 3: 1256-1266.

12. Sorenso WG (1999) Fungal Spores: hazardous to health? Environmental Health Perspective 107: 469-472.

13. Neekamal C, Kieren AM (2011) Impact of Aspergillus fumigates in allergic airway diseases. Clinical and Translational allergy 1: 4

14. Napoli C, Tafuri S, Montenegro L, Cassano M, Notarnicola et al. (2012) Air sampling methods to evaluate microbial contamination in operating theatres: results of a comparative study in an orthopaedics department. Journal of Hospital Infection 80: 128-132.

15. Emojevwe V, Okeremeta O, Loveth (2013) Aerial microbiology of the science building (ofrima complex) in the university of Port Harcourt. Advances in Agriculture, Sciences and Engineering Research 3: 809-815.

16. Buchannan RE, Gibbon NE (1974) Bergey's Manual of Determinative bacteriology. Williams and Wilkins Co. Baltimore.

17. Betty AF, Daniel FS, Alice SW (2007) Diagnostic Microbiology. Pp: 638-695

18. Burge HA (1989) Air borne allergenic fungi. Classification, nomenclature and distribution. Immunology and Allergy Clinics of North America 9: 307-319.

19. Kim KY, Kimb HT, Kim D, Nakajimad J, Higuchi T (2009) Distribution characteristics of airborne bacteria and fungi in the feed stuff manufacturing factories. Journal of Hazardous. Material 169: 1054-1060.

20. Wayne L, Nicholson N, Munakata GH, Henry Melosh J, Peter S (2000) Resistance of bacillus endospores to extreme terrestrial and extraterrestrial environment. Microbiology and Molecular Biology. Reviews 64: 548-572.

21. Whyte P, Collins JD, McGill K, Monahan C, O'Mahony H (2001) Distribution and prevalence of airborne microorganisms in three commercial poultry processing plants. Journal of Food Protection 64: 388-391.

22. WHO (1984) Programme for control of diarrhoeal diseases. 5th Programme Report (1984-1985). Geneva, WHO Bulletin.

23. Wojcik-Stopczynska B, Flakowski J, Jakubowska B (2003) Microflora of University Canteen Air. PZH Annals 54: 321-328.

24. Boone SA (2007) Significance of fomites in the spread of respiratory and enteric viral disease. Applied and Environmental Microbiology 73: 1687-1696.

25. Chen X, Ran P, Ho K, Lu W, Li B et al. (2012) Concentrations and size distributions of airborne microorganisms in Guangzhou during summer. Aerosol and Air quaity Research 12: 1336-1344.

26. A manual of laboratory exercises for introductory and general microbiology. Department of microbiology, University of Portharcourt Pp: 9-51.

27. Hu T, Cao J, Shen Z, Wang G, Lee S, et al. (2012) Size differentiation of individual atmospheric aerosol during winter in Xi'an, China. Aerosol and Air Quality Research 12: 951-960.

28. Kalwasinska A, Burkowska A, Wilk I (2012) Microbial air contamination in indoor environment of the University Library. Aerosol and Air Quality Research 19: $25-29$

29. Li Y, Qiu X, Li M, Ma Z, Niu T et al. (2012) Concentration and size distribution of airborne actinomycetes in a municipal wastewater treatment plant. Polish Journal of Environmental Studies 21: 1305-1311.

30. Marcio N, Elias A (2007) Clinical microbiology 20: 695-704

31. Marie V, Irena H, Jan S, Roman C, Vanda B, et al. (2011) Microbial air load a the Transplant Intensive Care Unit. Millitary Medical Science Letters 80: 52-57.

32. Treajan L, Pullam (1982) Medical microbiology: Laboratory procedures. WB Sauders. 